\title{
Advance Praise
}

"The Power of Cute examines an acute yet virtually unnoticed part of contemporary society, the rise of cuteness. A joy to read, this book is terrifyingly brilliant and continuously surprising, filled with subtle insights and wonderful theorizing." -Jeffrey C. Alexander, Yale University

"From powerlessness to tyranny, and from the fluffy dog in the window to Kim Jong-il's hairstyle, 'the cute' raises the abysmal issue of the world's desire for meaninglessness. Comforting and uncanny at the same time, cuteness incarnates nihilism as plenitude, infantilism as art, and desexualization as seduction. Simon May's humorous and profound book explores the secret dimensions of a new religion, raising the question: Is cuteness an attribute of God?"

\section{-Catherine Malabou, Kingston University London}

"We think we have power over cute things-but maybe the boot is on the other foot, and cute things manipulate us. The Power of Cute considers the notion that when we find things or people cute, ambivalence is in the air: on the one hand, cute things are infantile and unthreatening, on the other hand, uncanny or unsettling. This intelligent and thoughtprovoking book breaks new ground."

\section{-Simon Blackburn, author of Mirror, Mirror}

"In this highly readable and erudite book, Simon May develops a theory of 'the cute.' May probes a range of cases, particularly of artificial cuteness-Hello Kitty, Pokémon, E.T., Kewpie dolls-and gives searching reflections on what the ascendancy of cute might reflect about our broader societal values and present historical moment."

\section{-Andrew Huddleston, Birkbeck, University of London}


The Power of Cute 


\section{The Power of Cute}

Simon May

PRINCETON UNIVERSITY PRESS

Princeton and Oxford 
Copyright @ 2019 by Simon May

Published by Princeton University Press

41 William Street, Princeton, New Jersey 08540

6 Oxford Street, Woodstock, Oxfordshire OX20 1TR

press.princeton.edu

All Rights Reserved

Library of Congress Control Number: 2018957590

ISBN 978-0-691-18181-3

British Library Cataloging-in-Publication Data is available

Editorial: Sarah Caro, Hannah Paul, Charlie Allen

Production Editorial: Terri O'Prey

Text Design: Pamela Schnitter

Jacket/Cover Design: Amanda Weiss

Jacket/Cover Credit: Maneki-neko (Japanese "welcoming cat")

courtesy of Italika / iStock

Production: Jacqueline Poirier

Publicity: Caroline Priday and Julia Haav

Copyeditor: Molan Goldstein

This book has been composed in Cormorant Garamond

and Gotham

Printed on acid-free paper $\infty$

Printed in the United States of America

$\begin{array}{llllllllll}10 & 9 & 8 & 7 & 6 & 5 & 4 & 3 & 2 & 1\end{array}$ 
To Mimi, guru of Cute 
